\title{
Double blind, randomized, placebo controlled clinical trial for the treatment of diabetic foot ulcers, using a nitric oxide releasing patch: PATHON
}

\author{
Sandra Y Silva ${ }^{1}$, Ligia C Rueda ${ }^{1}$, Gustavo A Márquez ${ }^{1}$, Marcos López², \\ Daniel J Smith2 ${ }^{2}$ Carlos A Calderón ${ }^{3}$, Juan C Castillor, Jaime Matute ${ }^{4}$, \\ Christian F Rueda-Clausen ${ }^{1}$, Arturo Orduz ${ }^{1}$, Federico A Silva ${ }^{1}$, \\ Piyaporn Kampeerapappun², Mahesh Bhide ${ }^{2}$ and Patricio López- \\ Jaramillo*1,5
}

Address: 'VILANO Group. Research Institute, Fundación Cardiovascular de Colombia (FCV), Floridablanca, Santander, Colombia, ${ }^{2}$ Department of Chemistry, University of Akron, Akron, Ohio, USA, ${ }^{3}$ Fundación Santandereana de Diabetes y Obesidad (FUSANDE), Bucaramanga, Santander, Colombia, ${ }^{4}$ Instituto de Seguros Sociales, Bucaramanga, Santander, Colombia and ${ }^{5}$ Facultad de Medicina, Universidad de Santander, Bucaramanga, Santander, Colombia

Email: Sandra Y Silva - sandrasilvac@gmail.com; Ligia C Rueda - ligiarueda62@gmail.com; Gustavo A Márquez - piedegus@yahoo.es; Marcos López - marcoslopez@mcw.edu; Daniel J Smith - djs5@uakron.edu; Carlos A Calderón - calderindicor@hotmail.com; Juan C Castillo - juancarcastillo@latinmail.com; Jaime Matute - matutejaime42@yahoo.com; Christian F RuedaClausen - ruedaclausen@gmail.com; Arturo Orduz - aorduz@cable.net.co; Federico A Silva - fsilva5@hotmail.com; Piyaporn Kampeerapappun - st_bernard75@hotmail.com; Mahesh Bhide - maheshswara@yahoo.com; Patricio LópezJaramillo* - jplopezj@ hotmail.com

* Corresponding author

Published: 26 September 2007

Trials 2007, 8:26 doi:10.1186/1745-6215-8-26

This article is available from: http://www.trialsjournal.com/content/8/I/26

(c) 2007 Silva et al; licensee BioMed Central Ltd.

This is an Open Access article distributed under the terms of the Creative Commons Attribution License (http://creativecommons.org/licenses/by/2.0), which permits unrestricted use, distribution, and reproduction in any medium, provided the original work is properly cited.
Received: II July 2007

Accepted: 26 September 2007

\begin{abstract}
Background: Diabetes Mellitus constitutes one of the most important public health problems due to its high prevalence and enormous social and economic consequences. Diabetic foot ulcers are one of the chronic complications of diabetes mellitus and constitute the most important cause of non-traumatic amputation of inferior limbs. It is estimated that $15 \%$ of the diabetic population will develop an ulcer sometime in their lives. Although novel therapies have been proposed, there is no effective treatment for this pathology. Naturally produced nitric oxide participates in the wound healing process by stimulating the synthesis of collagen, triggering the release of chemotactic cytokines, increasing blood vessels permeability, promoting angiogenic activity, stimulating the release of epidermical growth factors, and by interfering with the bacterial mitochondrial respiratory chain. Topically administered nitric oxide has demonstrated to be effective and safe for the treatment of chronic ulcers secondary to cutaneous leishmaniasis. However, due to their unstable nitric oxide release, the topical donors needed to be applied frequently, diminishing the adherence to the treatment. This difficulty has led to the development of a multilayer polymeric transdermal patch produced by electrospinning technique that guarantees a constant nitric oxide release. The main objective of this study is to evaluate the effectiveness and safety of this novel nitric oxide releasing wound dressing for the treatment of diabetic foot ulcers.
\end{abstract}




\begin{abstract}
Methods and design: A double-blind, placebo-controlled clinical trial, including 100 diabetic patients was designed. At the time of enrollment, a complete medical evaluation and laboratory tests will be performed, and those patients who meet the inclusion criteria randomly assigned to one of two groups. Over the course of 90 days group I will receive active patches and group 2 placebo patches. The patients will be seen by the research group at least every two weeks until the healing of the ulcer or the end of the treatment. During each visit the healing process of the ulcer, the patient's health status and the presence of adverse events will be assessed. Should the effectiveness of the patches be demonstrated an alternative treatment would then be available to patients.
\end{abstract}

Trial registration: NCT00428727.

\section{Background}

Diabetes Mellitus (DM) constitutes one of the most important public health problems with a worldwide impact due to its high prevalence and enormous social and economic consequences. It is believed that there are more than 135 million diabetics, and this number is expected to increase to 300 million in the next 25 years (30\% in developed and $70 \%$ in developing countries) $[1,2]$.

This epidemic is related to several factors like ethnicity, the longer life expectancy, and the epidemiological and nutritional transition in developing countries due to the urbanization process that brings about obesity and sedentarism [3,4]. In Colombia, the 2002 basic health indicators showed a $2 \%$ prevalence of DM. However, it is believed that these numbers are underestimated [5]. Diabetic Foot Ulcers (DFU) are one of the chronic consequences of DM which constitute the most important cause of non-traumatic amputation of the Inferior Limbs (IL), and are associated with high human, social and economic costs [6-11]. It is estimated that approximately $15 \%$ of the diabetic population will develop a DFU some time in their life [12-16].

DFU is a consequence of two of the most frequent chronic complications of DM: Peripheral neuropathy and vascular insufficiency [12]. The combination of these factors in association with mechanic extrinsic and intrinsic aggressions, like feet bone deformations, triggers the ulcer formation. This polyfactorial etiopathology explains the multidisciplinary approach required for this disease [1719].

The early detection of risk factors for DFU may prevent their appearance [20-28]. This is why the monitoring of neuropathic, vascular and muscle-skeletal functions [29], the reinforcement of self care [30], the control of glycemic levels and the prevention of traumatic foot lesions $[21,23,24,31]$, have a positive impact on the prevention of this pathology.
The wound healing process involves the interaction of multiple cellular groups, extra cellular matrix molecules and growth factors [32], and is affected by vascular insufficiency, the severity of the lesion and the presence of infection $[18,24]$.

Immune and wound healing mechanism dysfunctions have been described in diabetic patients [33]. This alteration of the immune response is characterized by a decrease in the adherence of leukocytes to the capillary endothelium, chemotaxis damage and a reduction in the ability of polymorphonuclear cells to phagocyte and destroy bacteria due to a minor production of Nitric Oxide (NO) [34,35]. Diabetic patients also show a diminution in fibroblasts activity provoked by the unavailability of glucose for the aerobic metabolism, leading to inadequate fibrous collagen tissue proliferation [36]. The imbalance in these processes has been described as the main cause for the appearance and persistence of DFU [37].

Alternative therapies for DFU have been proposed, such as tissue engineering [38], growth factors [39], hyperbaric oxygen therapy $[40,41]$ and ketanserine $[42,43]$. Various types of products have also been used to keep the wound dry and covered (hydrogels, hydrocolloids, alginates and foams) [44], however, there is no effective treatment for this pathology $[45,46]$.

In normal conditions, NO is continuously produced [47] and is tightly linked to many physiological processes, among which wound healing. It has been described that NO stimulates collagen synthesis [48], triggers the release of chemotactic cytokines [49], and has an important microbicidal effect by interfering with the enzymatic processes of the bacterial mitochondrial respiratory chain [50]. It also increases blood vessels permeability [51-54], promotes angiogenic activity, and stimulates the release of epidermical growth factors $[37,55]$.

Various studies, performed in murine models, have demonstrated the role of $\mathrm{NO}$ in the healing process. The levels 
of the final metabolic products from NO (nitrite and nitrate) rise during the first two days more than subsequently in the liquid recovered from the sponges previously placed in the subcutaneous tissue of healthy subjects' wounds [56], increase that is not observed in diabetic subjects [54], suggesting an impairment in the cutaneous production of $\mathrm{NO}$ in diabetic individuals. The topical use of $\mathrm{NO}$ accelerates the wound healing process of excisional wounds [54,57] while NO inhibitors increase the healing time of these lesions $[48,58]$. The use of colloid NO donors in diabetic subjects shows an adequate granulation and closing of wounds $[59,60]$.

Our experience in the treatment of cutaneous leishmaniasis with s-nitroso- $\mathrm{N}$-acetilpenicilamine (SNAP), a $\mathrm{NO}$ donor, shows a beneficial effect without adverse events [61]. Moreover, a clinical trial is being conducted to study the effectiveness of a controlled NO releasing patch in the treatment of cutaneous leishmaniasis [62]. Currently, there are no studies using topical NO donors in humans with diabetic ulcers. Though the use of NO donors in healthy volunteers has shown an adequate NO diffusion rate to dermis, and an increase in the microcapillar blood flow [63], this method has demonstrated not to be effective due to the short half life and release span of NO [61].

This difficulty in controlling the stability and release of NO has led to the development of a new NO releasing patch (NOP). This device, produced by the electrospinning technique [64], is a multilayer polymeric transdermal patch in which the principal components are stabilized and encapsulated in nanofibers which guarantees a constant NO release upon its hydration.

Since it is well known that the system generates NO almost immediately, nitrite ions are bound to an ionic exchange resin $\left(\right.$ DOWEX $\left.^{\circledast}\right)$ in order to stabilize them, allowing a constant release of $3.5 \mu \mathrm{mol}$ of $\mathrm{NO}$ during 12 hours or more depending upon the dosage [64]. This device has been tested by our group for the treatment of cutaneous leishmaniasis obtaining encouraging results in the healing process with no report of serious adverse events [61]. Since there is no specific effective treatment for DFU our group proposes to investigate the topical use of NOP, elaborated by the electrospinning technique, for the treatment of DFU.

\section{Objectives}

\section{General Objective}

To evaluate the effectiveness and safety of NOP for the treatment of DFU.

\section{Specific Objectives}

1. To evaluate the healing process of DFU using a NOP compared with placebo.
2. To assess the healing process of infected DFU using a NOP compared with placebo.

3. To identify adverse events associated with the application of NOP.

\section{Methods and design}

Double blind, randomized, placebo controlled clinical trial.

\section{Sample size}

The sample was calculated according to the arccosine formula considering a power of $80 \%$ and a type I error of 0.05 . Assigning a successful rate of $30 \%$ in the control group and $60 \%$ in the active group, 95 participants will be needed. After adjusting for a loss rate of $5 \%$, the total number of patients that must be recruited is 100 (50 patients per group).

\section{Population}

The population will be composed of patients with a confirmed diagnosis of DM type 1 or 2 who present DFU, meet the inclusion criteria and don't present any criterion that could exclude them.

\section{Inclusion criteria}

1. Men and women 18 years or older.

2. Capacity of attending the visits at the research site.

3. Confirmed diagnosis of DM type 1 or 2 according to the guidelines from the American Diabetes Association (ADA).

4. Presence of 1 or more DFU, less than $15 \mathrm{~cm}$ in its biggest diameter, with a Texas University score $\leq 2$.

\section{Pharmacological treatment for glycemic control.}

6. Willingness to participate in the study and to sign the informed consent form.

\section{Exclusion criteria}

1. Unconfirmed DM diagnosis.

2. Any pathology that, based on the judgment of the researcher, could alter the course of DFU (neoplasias, immunological disorders, etc).

\section{Renal insufficiency requiring dialysis treatment.}

4. DFU with aTexas score $>2$.

5. Infected DFU with clinical or paraclinical findings suggesting osteomielytis. 
6. Critical ischemia of IL diagnosed by Doppler ultrasound and defined by ankle/arm index $<0.5$.

7. Clinical findings suggesting complicated venous insufficiency of IL.

8. Distal necrosis of the limb with the ulcer.

\section{Pregnant or breastfeeding women.}

10. Mentally or neurologically disabled patients that are considered not fit to approve their participation in the study.

\section{Refusal to give informed consent.}

\section{Study development}

See table 1.

\section{Logistic phase}

This phase will be managed by the physician in charge of the study and a professional nurse and will include the following activities.

1. Acquisition of the materials required for the development of the project.

2. Elaboration of flyers, promotional and educative material, procedures manual and Case Report Format (CRF).

4. Training of personnel that will participate in the study.

\section{Treatment randomization}

The treatment randomization will be realized by the epidemiologist of the Fundación Cardiovascular de Colombia (FCV). This randomization will be done in blocks in order to avoid long sequences of patients assigned to the same group and to reduce when possible, some of the bias inherent to the simple randomization process. Additionally, this randomization in blocks will facilitate the execution of interim analyses.

\section{Recruitment phase}

Patients will attend the screening visit at the FCV or at the offices of the physicians involved in the study.

\section{Screening visit}

During this visit a complete medical check-up, based on universally accepted techniques, will evaluate risk factors, DM complications, vascular and neuropathic compromise, medications and other therapies used for the treatment of DFU. The ankle/arm index will be obtained to rule out the presence of critical IL ischemia. The inclusion/ exclusion criteria will be applied and the selected candidates informed about the study after which they will sign an informed consent form. A blood sample will be withdrawn to determine the percentage of glycosilated hemoglobin (HbA1c), the levels of creatinine and fasting glucose, the hemogram, and the lipid profile.

The laboratory of the Research Institute of FCV and the laboratories of every other center will be in charge of the

Table I: Schedule of activities

\begin{tabular}{|c|c|c|c|c|c|c|c|c|}
\hline \multirow[b]{2}{*}{ PROTOCOL ACTIVITIES } & \multicolumn{8}{|c|}{ Follow-up visits } \\
\hline & Screening Visit & Initial Visit & Visit I & Visit 2 & Visit 3 & Visit 4 & Visit 5 & Final Visit \\
\hline SCHEDULE OF VISITS & & 0 & $15 \pm 5$ & $30 \pm 5$ & $45 \pm 5$ & $60 \pm 5$ & $75 \pm 5$ & $90 \pm 5$ \\
\hline Clinical History & $x$ & $x$ & $x$ & $x$ & $x$ & $x$ & $x$ & $x$ \\
\hline Physical Examination & $x$ & $x$ & $x$ & $x$ & $x$ & $x$ & $x$ & $x$ \\
\hline Inclusion/Exclusion criteria & $x$ & & & & & & & \\
\hline Informed Consent & $x$ & & & & & & & \\
\hline $\begin{array}{l}\text { Clinical assessment of vascular } \\
\text { compromise }\end{array}$ & $x$ & $x$ & $x$ & $x$ & $x$ & $x$ & $x$ & $x$ \\
\hline $\begin{array}{l}\text { Clinical assessment of neuropathic } \\
\text { compromise }\end{array}$ & & $x$ & & & & & & $x$ \\
\hline Laboratory tests & & $x$ & & & & & & $x$ \\
\hline Ankle/arm index & $x$ & & & & & & & \\
\hline Randomization & & $x$ & & & & & & \\
\hline Treatment administration & & $x$ & $x$ & $x$ & $x$ & $x$ & $x$ & \\
\hline Clinical assessment of the lesion & $x$ & $x$ & $x$ & $x$ & $x$ & $x$ & $x$ & $x$ \\
\hline Measurement of ulcers & $x$ & $x$ & $x$ & $x$ & $x$ & $x$ & $x$ & $x$ \\
\hline Photographic registration & & $x$ & $x$ & $x$ & $x$ & $x$ & $x$ & $x$ \\
\hline Education of patients & $x$ & $x$ & $x$ & $x$ & $x$ & $x$ & $x$ & $x$ \\
\hline Documentation of adverse events & $x$ & $x$ & $x$ & $x$ & $x$ & $x$ & $x$ & $x$ \\
\hline $\begin{array}{l}\text { Recording of concomitant } \\
\text { medications }\end{array}$ & $x$ & $x$ & $x$ & $x$ & $x$ & $x$ & $x$ & $x$ \\
\hline
\end{tabular}


processing of blood samples. All the tests will be elaborated using standard techniques.

1. Glycosilated hemoglobin: Chromatography.

2. Creatinine: Spectrophotometry.

3. Hemogram: Manual method.

4. Lipid profile: Spectrophotometry.

5. Fasting glucose: Spectrophotometry.

\section{Initial visit}

The selected patients will be scheduled for the initial visit. In this visit the patients will be randomly assigned to one of the two groups. Group 1 will receive NOP and Group 2 placebo patches. A complete medical evaluation will be performed, the ulcers measured, and their pictures taken. Neuropathy will be assessed using the modified validated neuropathic impairment score (NDS) [65]. Before taking the pictures, a graduated ruler will be placed next to the ulcers with a sticker marked with the identification code of the participant and the date of the visit. The first patch (active or placebo) will be applied on the lesion. All the information obtained will be registered in the CRFs. The treatment previously prescribed for DM or other concomitant pathologies, and the medical, surgical or orthopedic therapies for DFU will be continued with the exception of topical treatment. The researchers will follow the guidelines of the International Diabetic Foot Consensus (CIPD). The patient and his/her family will receive information regarding the treatment of DFU, the correct technique for the daily application of the patches and the identification and notification of adverse events.

\section{Follow-up visits}

The treatment will last 90 days. During this period, the patients will be seen by the research group at least every two weeks until the healing of the ulcer or the end of the treatment. The frequency of the visits will vary depending on the clinical evolution of the patients. During each visit the healing process of the ulcer, the patient's health status and the presence of adverse events will be assessed. The patch will be applied and the evolution of the ulcers photographically registered. The maximum and minimum diameters of the ulcer will be measured using a graduated ruler and then registered in the CRF. The technique for the application of the patches, the identification of adverse events and the importance of reporting them, will be emphasized.

\section{Final visit}

The final visit will take place at the end of the treatment or before in case of complete healing of the ulcer. A thorough medical evaluation, including laboratory tests will be performed along with the assessment of vascular and neuropathic compromise. The presence of adverse events will also be evaluated. The evolution of the ulcers will be documented by measuring their maximum and minimum diameters and by photographing them.

\section{National Coordination from Monitoring Center}

Every six months a researcher from FCV will visit each center to evaluate the fulfillment of the protocol and the accomplishment of the Good Clinical Practice.

\section{Data base depuration phase}

After completing all the data entry to the CRF the results will be audited and the detected errors evaluated and corrected. The information will be entered in two different databases by two different people and the records compared to detect any discrepancy using a statistical software (Epi-Info 6.04). The mistakes will be corrected according to the CRF, and the corrections registered.

Each patient will be identified using an internal code. All the photographs will be processed using a digital edition software.

\section{Statistical analysis}

For the statistical analysis, Stata 8.0 will be used. The descriptive analysis will be composed of medians and proportions according to the nature of the variables, with their respective $95 \%$ confidence intervals. As a dispersion measurement the standard deviation will be calculated. The distribution of the variables will be studied using the Shapiro-Wilk test and the homocedasticity of the variances with the Levene test. To detect any difference between the groups, a T-test or a Mann Whitney test will be performed according to the distribution of the variables. The categorical variables will be compared using the $\mathrm{Chi}^{2}$ test or the exact Fisher's test. If required, a model of multiple logistic regressions or a covariance analysis will be realized. Two interim analyses will be performed when 35 and $70 \%$ of the total sample is collected to determine differences in effectiveness and safety between the groups.

\section{Endpoints}

At the end of the treatment the following endpoints will be evaluated:

\section{Ulcer reduction percentage.}

2. Complete cure of the infection that was present before the treatment.

3. Infection of the ulcers during the treatment. 
4. Presence of adverse events related to the application of the patches.

\section{Final report}

The results of the study will be evaluated and discussed and a final report presented to the Federación Diabetológica Colombiana (FDC), entity that is sponsoring the project. The results will be submitted for publication and presented in congresses and scientific meetings.

\section{Ethical aspects}

This study will be conducted in accordance with the Declaration of Helsinki and with the Colombian legislation as per the Resolution 8430/93 from the Ministry of Health. Prior to the admission of the patients in the study, the objectives and the methodology will be explained and a written informed consent obtained. The study was approved by the Research Ethic Committee of the FCV (Act\# 075/April 27/2004). The patients' right to confidentiality will be maintained in all the phases of the study.

\section{Evaluation and management of adverse events}

During the visits the patients will be asked about adverse events. Each adverse event will be classified by the physician as serious or non-serious. A serious adverse event should meet one or more of the following criteria:

\section{Death}

\section{Life-threatening}

3. Hospitalization or prolongation of existing hospitalization

\section{Persistent or significant disability/incapacity}

The presence of a serious adverse event that puts the patient's life at risk and/or requires immediate medical or surgical procedure will call for the discontinuation of the treatment and the initiation of the pertinent medical management. The investigator will notify the Adverse Event Committee (AEC) of the FCV of any serious adverse event within 24 hours of learning about it.

A non-serious adverse event will be classified as follows:

1. Mild: The patient is aware of his/her symptoms and/or signs, but those are tolerable. Medical intervention or specific treatment is not required.

2. Moderate: The patients present troubles that interfere with his/her daily activities. Medical intervention or specific treatment is required.
3. Severe: The patient is unable to work or to attend his/ her daily activities. Medical intervention or specific treatment is required.

The possible relationship between the adverse events and the tested medication will be classified by the investigator on the basis of his/her clinical judgment and the following definitions:

1. Definitely related: Event can be fully explained by the administration of the tested medication.

2. Probably related: Event is most likely to be explained by the administration of the tested medication rather than other medications or by the patient's clinical state.

3. Possibly related: Event may be explained by the administration of the tested medication or other medications or by the patient's clinical state.

4. Not related: Event is most likely to be explained by the patient's clinical state or by the use of other medications, rather than the tested one.

All the events will be reported to the AEC that, depending on its criteria, will decide the continuity of the patient in the study and therefore the breaking of the code. Although the project has been designed to minimize the inherent risks, any adverse event related to the study medication will be carefully evaluated by the AEC and the costs generated by the required treatment covered by the study.

\section{Competing interests}

The author(s) declare that they have no competing interests.

\section{Authors' contributions}

PLJ made substantial contributions to the conception and design of the study, will be responsible for the administration and direction of the project, the analysis and interpretation of data and will give the final approval of the manuscript to be published. DS, who participated in the design of the project, will be responsible for the production and analysis of the NO releasing electrospun nanofiber patches. GAM made substantial contributions to the conception and design of the study and will be responsible for analyzing and interpreting the final data. $\mathrm{ML}, \mathrm{PK}$ and $\mathrm{MB}$ were in charge of the development of the NO releasing patches, the drafting of the manuscript and will participate in the analysis and interpretation of data. JCC, CAC, JM, AO will be responsible for overseeing the logistics of the clinical trial and will interpret the final data. FAS contributed to the conception and design of the study, performed sample size calculation and randomization and will analyze the data obtained from the clinical 
trial. SYS, CFR and LCR made substantial contributions to the conception and design of the study and were involved in drafting the manuscript. All authors read and approved the final manuscript.

\section{Acknowledgements}

This study is supported by a grant from FDC, and funds from the Research Institute of FCV and from the University of Akron Research Foundation.

We would like to express our gratitude to Jean Noël Guillemot for reviewing the English style.

\section{References}

I. World Health Organization: Control of hereditary diseases. Report of a WHO Scientific Group. Ginebra: WHO Techn Rep Ser. 865 1996. Ref Type: Report

2. King $H$, Aubert RE, Herman WH: Global burden of diabetes, 1995-2025: prevalence, numerical estimates, and projections. Diabetes Care 1998, 21:|4|4-|431.

3. Yusuf S, Reddy S, Ounpuu S, Anand S: Global burden of cardiovascular diseases: part I: general considerations, the epidemiologic transition, risk factors, and impact of urbanization. Circulation 200I, 104:2746-2753.

4. Aschner P: Diabetes trends in Latin America. Diabetes Metab Res Rev 2002, 18(Suppl 3):S27-S3I.

5. Ministerio de Salud. Centro Nacional de Consultoría: III Estudio de Salud bucal - ENSAB III. II Estudio Nacional de factores de riesgo de enfermedades crónicas - ENFREC II. Tomo V: Prevalencia de diabetes mellitus y glucosa alterada en ayunas 1999.

6. Peyrot M, Rubin RR: Levels and risks of depression and anxiety symptomatology among diabetic adults. Diabetes Care 1997, 20:585-590.

7. Gordois A, Scuffham P, Shearer A, Oglesby A, Tobian JA: The health care costs of diabetic peripheral neuropathy in the US. Diabetes Care 2003, 26:1790-1795.

8. Glasgow RE, Ruggiero L, Eakin EG, Dryfoos J, Chobanian L: Quality of life and associated characteristics in a large national sample of adults with diabetes. Diabetes Care 1997, 20:562-567.

9. Brod M: Quality of life issues in patients with diabetes and lower extremity ulcers: patients and care givers. Qual Life Res 1998, 7:365-372.

10. Ashry HR, Lavery LA, Armstrong DG, Lavery DC, van Houtum WH: Cost of diabetes-related amputations in minorities. I Foot Ankle Surg 1998, 37: 186-190.

11. Apelqvist J: Wound healing in diabetes. Outcome and costs. Clin Podiatr Med Surg 1998, 15:21-39.

12. Reiber GE: The epidemiology of diabetic foot problems. Diabet Med 1996, I3(SuppI I):S6-II.

13. Ramsey SD, Newton K, Blough D, McCulloch DK, Sandhu N, Reiber GE, Wagner EH: Incidence, outcomes, and cost of foot ulcers in patients with diabetes. Diabetes Care 1999, 22:382-387.

14. Kantor J, Margolis D]: Treatment options for diabetic neuropathic foot ulcers: a cost-effectiveness analysis. Dermatol Surg 200I, 27:347-35I.

15. Boulton A): The diabetic foot: a global view. Diabetes Metab Res Rev 2000, I6(Suppl I):S2-S5.

16. Comparing the incidence of lower extremity amputations across the world: the Global Lower Extremity Amputation Study. Diabet Med 1995, I 2:14-18.

17. Boyko El, Ahroni JH, Stensel V, Forsberg RC, Davignon DR, Smith DG: A prospective study of risk factors for diabetic foot ulcer. The Seattle Diabetic Foot Study. Diabetes Care 1999, 22:1036-1042.

18. Frykberg RG, Armstrong DG, Giurini J, Edwards A, Kravette M, Kravitz S, Ross C, Stavosky J, Stuck R, Vanore J: Diabetic foot disorders. A clinical practice guideline. For the American College of Foot and Ankle Surgeons and the American College of Foot and Ankle Orthopedics and Medicine. I Foot Ankle Surg 2000:1-60.

19. Consensus Development Conference on Diabetic Foot Wound Care: 7-8 April Boston, Massachusetts. American Diabetes Association. Diabetes Care 1999, 22:1354-1360.
20. Armstrong DG, Lavery LA: Diabetic foot ulcers: prevention, diagnosis and classification. Am Fam Physician 1998, 57:1325-1328.

21. Armstrong DG: Is diabetic foot care efficacious or cost effective? Ostomy Wound Manage 200I, 47:28-32.

22. Dargis V, Pantelejeva O, Jonushaite A, Vileikyte L, Boulton AJ: Benefits of a multidisciplinary approach in the management of recurrent diabetic foot ulceration in Lithuania: a prospective study. Diabetes Care 1999, 22:1428-|43I.

23. Frykberg RG: Team approach toward lower extremity amputation prevention in diabetes. J Am Podiatr Med Assoc 1997, 87:305-3।2.

24. Frykberg RG: Diabetic foot ulcers: current concepts. J Foot Ankle Surg 1998, 37:440-446.

25. Holstein PE, Sorensen S: Limb salvage experience in a multidisciplinary diabetic foot unit. Diabetes Care 1999, 22(Suppl 2):B97-103.

26. Mayfield JA, Reiber GE, Sanders LJ, Janisse D, Pogach LM: Preventive foot care in people with diabetes. Diabetes Care 1998, 2I:216I-2I77.

27. Ortegon MM, Redekop WK, Niessen LW: Cost-effectiveness of prevention and treatment of the diabetic foot: a Markov analysis. Diabetes Care 2004, 27:90I-907.

28. Valk GD, Kriegsman DM, Assendelft WJ: Patient education for preventing diabetic foot ulceration. Cochrane Database Syst Rev 200I:CD00I 488.

29. Boulton AJ, Gries FA, Jervell JA: Guidelines for the diagnosis and outpatient management of diabetic peripheral neuropathy. Diabet Med 1998, I 5:508-5/4.

30. Edmonds $M$, Boulton A, Buckenham $T$, Every N, Foster A, Freeman D, Gadsby R, Gibby O, Knowles A, Pooke M, Tovey F, Unwin N, Wolfe J: Report of the Diabetic Foot and Amputation Group. Diabet Med 1996, 13:S27-S42.

31. Mayfield JA, Reiber GE, Sanders LI, Janisse D, Pogach LM: Preventive foot care in diabetes. Diabetes Care 2004, 27(SuppI I):S63-S64.

32. Nanney LB, Caldwell RL, Pollins AC, Cardwell NL, Opalenik SR, Davidson JM: Novel approaches for understanding the mechanisms of wound repair. J Investig Dermatol Symp Proc 2006, I I:132-139.

33. Geerlings SE, Hoepelman Al: Immune dysfunction in patients with diabetes mellitus (DM). FEMS Immunol Med Microbiol 1999, 26:259-265.

34. File TM Jr, Tan JS: Infectious complications in diabetic patients. Curr Ther Endocrinol Metab 1997, 6:49I-495.

35. Calvet HM, Yoshikawa TT: Infections in diabetes. Infect Dis Clin North Am 200I, I5:407-2I.

36. Silhi N: Diabetes and wound healing. J Wound Care 1998, 7:47-5I.

37. Robson MC: The role of growth factors in the healing of chronic wounds. Wound Repair Regen 1997, 5:12-17.

38. Veves A, Falanga V, Armstrong DG, Sabolinski ML: Graftskin, a human skin equivalent, is effective in the management of noninfected neuropathic diabetic foot ulcers: a prospective randomized multicenter clinical trial. Diabetes Care 200I, 24:290-295.

39. Richard JL, Parer-Richard C, Daures JP, Clouet S, Vannereau D, Bringer J, Rodier M, Jacob C, Comte-Bardonnet M: Effect of topical basic fibroblast growth factor on the healing of chronic diabetic neuropathic ulcer of the foot. A pilot, randomized, double-blind, placebo-controlled study. Diabetes Care 1995, 18:64-69.

40. Faglia E, Favales F, Aldeghi A, Calia P, Quarantiello A, Oriani G, Michael M, Campagnoli $P$, Morabito A: Adjunctive systemic hyperbaric oxygen therapy in treatment of severe prevalently ischemic diabetic foot ulcer. A randomized study. Diabetes Care 1996, 19:1338-1343.

4I. Leslie CA, Sapico FL, Ginunas VJ, Adkins RH: Randomized controlled trial of topical hyperbaric oxygen for treatment of diabetic foot ulcers. Diabetes Care 1988, I I:III-II5.

42. Martinez-de Jesus FR, Morales-Guzman M, Castaneda M, PerezMorales A, Garcia-Alonso J, Mendiola-Segura I: Randomized single-blind trial of topical ketanserin for healing acceleration of diabetic foot ulcers. Arch Med Res 1997, 28:95-99.

43. Apelqvist J, Castenfors J, Larsson J, Stenstrom A, Persson G: Ketanserin in the treatment of diabetic foot ulcer with severe peripheral vascular disease. Int Angiol 1990, 9:120-124. 
44. Hogge J, Krasner D, Nguyen H, Harkless LB, Armstrong DG: The potential benefits of advanced therapeutic modalities in the treatment of diabetic foot wounds. J Am Podiatr Med Assoc 2000, 90:57-65.

45. O'Meara S, Cullum N, Majid M, Sheldon T: Systematic reviews of wound care management: (3) antimicrobial agents for chronic wounds; (4) diabetic foot ulceration. Health Technol Assess 2000, 4(21): I-237.

46. Mason J, O'Keeffe C, Hutchinson A, McIntosh A, Young R, Booth A: A systematic review of foot ulcer in patients with Type 2 diabetes mellitus. II: treatment. Diabet Med 1999, 16:889-909.

47. Weller R, Pattullo S, Smith L, Golden M, Ormerod A, Benjamin N: Nitric oxide is generated on the skin surface by reduction of sweat nitrate. J Invest Dermatol 1996, 107:327-331.

48. Schaffer MR, Tantry U, Thornton FJ, Barbul A: Inhibition of nitric oxide synthesis in wounds: pharmacology and effect on accumulation of collagen in wounds in mice. Eur J Surg 1999, 165:262-267.

49. Xiong M, Elson G, Legarda D, Leibovich SJ: Production of vascular endothelial growth factor by murine macrophages: regulation by hypoxia, lactate, and the inducible nitric oxide synthase pathway. Am J Pathol 1998, I53:587-598.

50. Ghaffari A, Miller CC, McMullin B, Ghahary A: Potential application of gaseous nitric oxide as a topical antimicrobial agent. Nitric Oxide \% 2006, I 4(I):2I-9. Epub.2005.Sep.26

5I. Lee PC, Salyapongse AN, Bragdon GA, Shears LL, Watkins SC, Edington HD, Billiar TR: Impaired wound healing and angiogenesis in eNOS-deficient mice. Am J Physiol 1999, 277:HI600-HI 608.

52. Nissen NN, Polverini PJ, Koch AE, Volin MV, Gamelli RL, DiPietro LA: Vascular endothelial growth factor mediates angiogenic activity during the proliferative phase of wound healing. Am J Pathol 1998, 152: 1445-1452.

53. Stallmeyer B, Kampfer H, Kolb N, Pfeilschifter J, Frank S: The function of nitric oxide in wound repair: inhibition of inducible nitric oxide-synthase severely impairs wound reepithelialization. J Invest Dermatol 1999, I I 3:1090-1098.

54. Witte MB, Thornton FJ, Tantry U, Barbul A: L-Arginine supplementation enhances diabetic wound healing: involvement of the nitric oxide synthase and arginase pathways. Metabolism 2002, 5 I: I269-1273.

55. Krischel V, Bruch-Gerharz D, Suschek C, Kroncke KD, Ruzicka T, Kolb-Bachofen V: Biphasic effect of exogenous nitric oxide on proliferation and differentiation in skin derived keratinocytes but not fibroblasts. J Invest Dermatol 1998, I I I:286-291.

56. Albina JE, Mills CD, Henry WL Jr, Caldwell MD: Temporal expression of different pathways of I-arginine metabolism in healing wounds. J Immunol 1990, 144:3877-3880.

57. Shabani M, Pulfer SK, Bulgrin JP, Smith DJ: Enhancement of wound repair with a topically applied nitric oxide-releasing polymer. Wound Repair Regen 1996, 4:353-362.

58. Schaffer MR, Tantry U, Gross SS, Wasserburg HL, Barbul A: Nitric oxide regulates wound healing. J Surg Res 1996, 63:237-240.

59. Masters KS, Leibovich SJ, Belem P, West JL, Poole-Warren LA: Effects of nitric oxide releasing poly(vinyl alcohol) hydrogel dressings on dermal wound healing in diabetic mice. Wound Repair Regen 2002, 10:286-294.

60. Witte MB, Kiyama T, Barbul A: Nitric oxide enhances experimental wound healing in diabetes. Br J Surg 2002, 89: I594-160I.

61. Lopez-Jaramillo P, Ruano C, Rivera J, Teran E, Salazar-Irigoyen R, Esplugues JV, Moncada S: Treatment of cutaneous leishmaniasis with nitric-oxide donor. Lancet 1998, 35 I: I I76-I I77.

62. Silva SY, Rueda LC, Lopez M, Velez ID, Rueda-Clausen CF, Smith DJ, Munoz G, Mosquera H, Silva FA, Buitrago A, Diaz H, Lopez-Jaramillo $P$ : Double blind, randomized controlled trial, to evaluate the effectiveness of a controlled nitric oxide releasing patch versus meglumine antimoniate in the treatment of cutaneous leishmaniasis [NCT003 I7629]. Trials 2006, 7:14

63. Hardwick JB, Tucker AT, Wilks M, Johnston A, Benjamin N: A novel method for the delivery of nitric oxide therapy to the skin of human subjects using a semi-permeable membrane. Clin Sci (Lond) 200I, 100:395-400.

64. Smith D, Lopez-Jaramillo P, Lopez M: Nitric Oxide Donor Devices. [WO 2006/0583 I 8]. 2006. Ref Type: Patent

65. Sinnreich M, Taylor BV, Dyck PJ: Diabetic neuropathies. Classification, clinical features, and pathophysiological basis. Neurologist 2005, I I:63-79.
Publish with Bio Med Central and every scientist can read your work free of charge

"BioMed Central will be the most significant development for disseminating the results of biomedical research in our lifetime. "

Sir Paul Nurse, Cancer Research UK

Your research papers will be:

- available free of charge to the entire biomedical community

- peer reviewed and published immediately upon acceptance

- cited in PubMed and archived on PubMed Central

- yours - you keep the copyright 